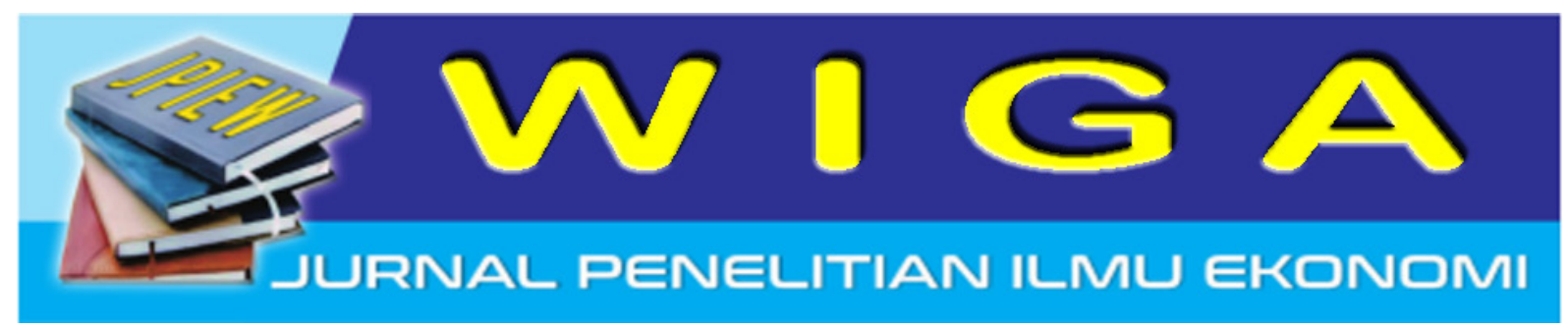

\title{
IDENTIFIKASI MASALAH DAN POTENSI DESA BERBASIS INDEK DESA MEMBANGUN (IDM) DI DESA GONDOWANGI KECAMATAN WAGIR KABUPATEN MALANG
}

\author{
Moh. hudi Setyobakti \\ STIE Widya Gama Lumajang \\ hudisetyobakti@gmail.com
}

\begin{abstract}
Abstrak
Penelitian ini bertujuan mendiskripsikan keadaan desa berbasis Indeks Desa Membangun (IDM) sebagaimana regulasi Permendesa nomor 2 tahun 2016. Metode yang digunakan dengan pendekatan Community Based Research yang dilakukan secara kualitatif.Proses pengumpulan data dilakukan dengan menggunakan variabel dan indikator IDM.

Hasil penelitian menunjukkan bahwa Desa Gondowangi adalah desa dengan kategori sub urban, sehingga sifat masyarakatnya menyatu, tidak terpisah secara geografis. Desa gondowangi dekat dengan pusat pelayanan masyarakat termasuk yang dibangun oleh desa. Sarana dan prasarana desa khususnya terkait dengan pelayanan dasar telah terpenuhi, kekurangan hanya hanya perlu optimalisasi pemanfaatan. Sedangkan potensi yang menunjang adalah ketersediaan SDM, Pemerintah desa yang pro aktif, kearifan lokal yang sudah berjalan seperti pengelolaan sampah, kelembagaan ekonomi desa berupa Bumdesa yang sudah berjalan.
\end{abstract}

Kata kunci: Identifikasi, IDM.

\begin{abstract}
Abstrac
This study aimed to describe the state of the index-based village building (IDM) as the regulatory Permendesa number 2 in 2016. The method used by the approach of Community-Based Research conducted qualitatively. The process of data collection is done by using variables and indicators of IDM.

The results showed that Gondowangi village is the village with sub-urban categories, so that the nature of the people together, not separated geographically. Gondowangi village near to the center of public services including those built by the village. Facilities and infrastructure of the village, especially related to basic services are met, the only drawback just need to optimize utilization. While the potential of that support is the availability of human resources, the village government pro-active, local wisdom which has been running such as waste management, rural economic institutions in the form of Bumdesa already running.
\end{abstract}

Keywords:Identificat,IDM 


\section{LATAR BELAKANG MASALAH}

Undang Undang No. 6 Tahun 2014 Tentang Desa atau UU Desa merupakan instrumen hukum untuk mencapai kesejahteraan masyarakat dan kemandirian Desa.Penjelasan tentang Desa adalah "Desa dan Desa Adat atau yang disebut dengan nama lain, selanjutnya disebut Desa, adalah kesatuan masyarakat hukum yang memiliki batas wilayah yang berwenang untuk mengatur dan mengurus urusan pemerintahan, kepentingan masyarakat setempat berdasarkan prakarsa masyarakat, hak asal usul, dan/atau hak tradisional yang diakui dan dihormati dalam sistem pemerintahan Negara Kesatuan Republik Indonesia." (UU Desa; 2014). Penjelasan tersebutmemberikan gambaran jelas tentang pengertian Desa, prinsip dan tujuan pembangunan Desa yang mengedepankan posisi Desa dengan kewenangannya berdasar hukum. Dari empat (4) kewenangan Desa, dua diantaranya dan utama adalah Kewenangan berdasar hak asal usul dan Kewenangan lokal berskala Desa.Dua kewenangan tersebut menjadi kekuatan penting bagi Desa menggerakan pembangunan dan peningkatan kualitas hidup, serta kesejahteraan masyarakat Desa.

Berdasarkan penjelasan diatas, Desa mempunyai peran yang cukup besar dalam upaya bagaimana menentukan arah visi yang hendak dicapai. Aspek penting dalam proses pencapaian visi tersebut adalah pembangunan desa. Dalam hal pembangunan desa, maka instrumen penting yang perlu diketahui adalah bagaimana sebenarnya permasalahan yang dialami oleh desa dan seberapa besar atau kuat potensi desa yang dimiliki. Kementrian desa melalui permendesa no 2 tahun 2016, telah menetapkan beberapa indikator yang memberikan kemudahan bagi desa untuk mengetahui sejauh mana tingkat kemandirian desa. Melalui instrumen inilah desa dapat mengenali dengan menggali informasi, sejauh mana permasalahan yang dialami terkait pembangunan desa dan potensi yang dimiliki untuk mendorong desa keluar dari jerat masalahnya.

\section{PERUMUSAN MASALAH}

Berdasarkan uraian latar belakang, rumusan masalah dalam penelitian yang akan dilakukanadalah; a. Mengenali bagaimana permasalahan pembangunan yang terjadi di desa?

b. Potensi apa yang dimiliki oleh desa, yang dapat dioptimalkan untuk mengatasi atau meminimalisir permasalahan yang ada?

\section{MANFAAT PENELITIAN}

Hasil penelitian ini diharapkan dapat memberikan manfaat atau kontribusi yang positif bagi Pengambil kebijakan, dapat dijadikan sebagai dasar pengambilan keputusan dalam rangka melakukan upaya menentukan kerangka kegiatan atau tematik kegiatan yang sesuai dengan kondisi permasalahan desa berbasis pada kearifan lokal yang inovatif.

\section{LANDASAN TEORI}

a. Definisi Desa.

Menurut UU Nomor 6 Tahun 2014 (UU Desa), definisi desa adalah desa dan desa adat atau yang disebut dengan nama lain, adalah kesatuan masyarakat hukum yang memiliki batas wilayah yang berwenang untuk mengatur dan mengurus urusan pemerintahan, kepentingan masyarakat setempat berdasarkan prakarsa masyarakat, hak asal usul, dan/atau hak tradisional yang diakui dan dihormati dalam sistem pemerintahan Negara Kesatuan Republik Indonesia (NKRI). Sebagai wakil negara, desa wajib melakukan pembangunan, baik pembangunan fisik maupun pembangunan sumber daya manusia, sebagai upaya peningkatan kualitas hidup dan kehidupan untuk sebesar-besarnya kesejahteraan masyarakat desa. Pembangunan desa yang berkelanjutan merupakan pembangunan desa yang tidak merusak lingkungan dan memberi hak kedaulatan untuk mengatur dirinya (Susetiawan, 2011).

b. Pembangunan Desa

Menurut Siagian, 2005:4), memberikan pengertian tentang pembangunan sebagai "suatu usaha atau rangkaian usaha pertumbuhan dan perubahan yang berencana dan dilakukan secara sadar oleh suatu bangsa, Negara dan pemerintah, menuju modernitas dalam rangka pembinaan bangsa". Pada hakekatnya pembangunan merupakan suatu kegiatan yang disengaja antara pemerintah dan melibatkan peran serta masyarakat dalam menuju usaha modernitas dengan perencanaan yang arah. 
c. Indeks Desa Membangun

Penjelasan Permendesa nomor 2 tahun 2016, memberikan kerangka pemikiran tentang pencapaian sasaran pembangunan Desa sebagaimana termuat dalam dokumen Rencana Pembangunan Jangka Menengah Nasional 2015 - 2019, penyusunan Indeks Desa Membangun dimaksudkan untuk menyediakan ukuran yang mampu melihat posisi dan status desa serta arah tingkat kemajuan dan kemandirian Desa. Indeks Desa Membangun (IDM) antara lain untuk (a) menjadi intrumen dalam menempatkan status/posisi desa dan menilai tingkat kemajuan dan kemandirian Desa; (b) menjadi bahan penyusunan target lokasi (lokus) berbasis desa, (c) menjadi instrumen koordinasi dengan K/L, Pemerintah Daerah dan Desa, serta lembaga lain. Melalui Indeks Desa Membangun status kemajuan dan kemandirian Desa tergambar dengan status Desa Mandiri (atau bisa disebut sebagai Desa Sembada), Desa Maju (atau bisa disebut sebagai Desa Pra-Sembada), Desa Berkembang (atau bisa disebut sebagai Desa Madya), Desa Tertinggal (atau bisa disebut sebagai Desa Pra-Madya) dan Desa Sangat Tertinggal (atau bisa disebut sebagai Desa Pratama).Klasifikasi yang lebih luas dalam 5 jenis status Desa diperlukan untuk mengakomodir keragaman dan kedalaman isu isu yang melekat di Desa.Seperti diketahui bersama, isu-isu Desa sejauh ini merupakan isu yang kompleks. Tantangannya adalah merepresentasikan kompleksitas itu ke dalam status, sehingga perumusan isu dan targeting (fokus dan lokus) lebih terarah dan terpusat. Alasan lain adalah menghindari moral hazard dalam mencapai sasaran sasaran pembangunan desa sehingga tidak mengulangi praktekpraktek pembangunan yang serba bias dan merugikan kehidupan Desa.

\section{METODE PENELITIAN}

Jenis penelitian yang digunakan dalam penelitian ini adalah deskriptif kualitatif. dengan mendeskripsikan data yang diperoleh yang selanjutnya dijabarkan dalam bentuk penjelasan, kemudian data yang diperoleh dianalisis secara kualitatif, dalam hal ini penelitian harus aktif dan menggunakan diri sendiri sebagai instrumen, mengikuti asumsiasumsi kultur sekaligus mengikuti data dalam upaya mencapai wawasan imajinatif ke dalam dunia sosial informan. Peneliti diharapkan fleksibel dan relektif tetapi tetap mampu mengatur jarak.

Menurut Nawawi (2005:63) Metode deskriptif dapat diartikan sebagai prosedur pemecahan masalah yng diselidiki dengan menggambarkan/melukiskan keadaan subyek/obyek penelitian (seseorang, lembaga, masyarakat dan lain-lain) pada saat sekarang berdasarkan fakta-fakta yang tampak atau sebagaimana adanya. MenurutLexyJ.Moleong(2006:6), bahwapenelit ian kualitatif adalah penelitian yang bermaksud untuk memahami fenomena tentang apayang dialami oleh subjek penelitian misalnya perilaku, persepsi, motivasi, tindakan,dan lain-lain secara holistik,dan dengan cara deskriptif dalam bentuk kata-kata dan bahasa, pada suatu konteks khusus yang alamiah dan dengan memanfaatkan berbagaimetode alamiah.

\section{TEKNIK PENGUMPULAN DATA}

Pengumpulan data dilaksanakan antara tanggal 16 Agustus 2016 sampai dengan 1 September 2016. Penelitian ini menggunakan pendekatan community based research(CBR). Pendekatan tersebut digunakan untuk menggali pemahaman yang luas dari masyarakat desa ditingkat mikro, messo, dan makro mengenai potensi desa secara keseluruhan, serta mengkaji arah dan motivasi pembangunan ekonomi perdesaan. Untuk memperoleh data daninformasi yang tepat, pengumpulan data dilakukan dengan cara:

a. Observasi keadaan desa secara langsung maupun mempelajari dokumen- dokumen milikdesa yang menjadi data sekunder.

b. Personal interview padaorang-orang kunci keystakeholder) desa,yaitu kepala desa, perangkat desa, pegiat kelompok masyarakat, tokohma syarakat,dan pelakuusahadidesa.Personalinterviewdilak ukan kepada minimal 10 keystakeholder dan bertujuan untuk menggali informasi dasar tentang permasalahan permasalahan yang terjadi dan dialami, dirasakan ataupun diamati baik secara langsung maupun tidak langsung oleh narasumber. Pengkayaan informasi melalui personal interview, dilakukan tidak hanya sebelum FGD tetapi juga dilakukan pasca FGD, dengan tujuan memperkuat informasi yang diberikan.

c. Focus Group Discussion, diskusi ini 
melibatkan kelembagaan desa, wakil masyarakat, dengan tujuan mendapatkan informasi keadaan desa, sejauhmana persoalan persoalan yang dihadapi oleh desa dan upaya yang telah dilakukan desa beserta hambatan hambatan dan potensi yang memungkinkan dioptimalkan.

d. Pengamatan langsung pada titik lokasisecara sampling berdasarkan apa yang diinformasikan dalam forum FGD ataupun wawancara dengan key person sebelumnya. Hal ini sebagai upaya cross check atas informasi yang diperoleh dari langkah-langkah pengumpulan data sebelumnya dan menemukan persoalan persoalan yang dihadapi desa dalam kontek pembangunan desa beserta potensi potensi yang memungkinkan dioptimalkan dalam upaya penanganan terhadap permasalahan tersebut.Dalam riset tahap ini merupakan bagian dari teknik triangulasi sumber.

\section{MODEL PENELITIAN}

Pendekatan dalam penelitian ini, adalah pendekatan metode kualitatif, untuk mendapatkan hasil penelitian yang diharapkan, maka model penelitian yang dikembangkan adalah sebagai berikut;

Gambar 4.2

Model Penelitian

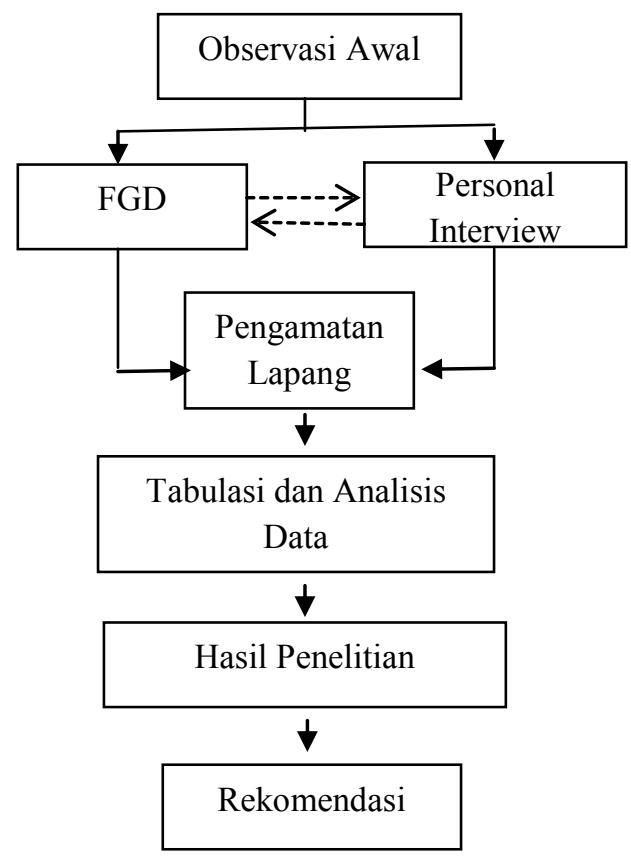

VIII. TEKNIK ANALISIS DATA

Penelitian ini menggunakan pendekatan Community Based Research yang dilakukan secara kualitatif. Secara umum strategi analisa data pada penelitian kualitatif adalah:1) Meletakkan informasi pada susunan yang berbeda; 2)Membuat matriks atau kategori dan menempatkan buktibukti pada kategori tersebut;3) Membuat datadisplay; 4) Membuat tabulasi dari kejadian-kejadian yang berbeda; 5) menguji kompleksitas dari tabulasi yang dibuat; dan6) menyusun informasi dalam urutan kronologi (Milesdan Huberman,1992).

Proses analisis dalam penelitian ini fokus pada penggalian informasi tentang permasalahan yang dihadapi oleh desa dan potensi yang dimiliki oleh desa terkait dengan pembangunan desa berbasis pada indek desa membangun.Kerangka pikir proses analis data didasarkan atas teori-teori diatas, maka proses analisa data dilakukan dengan tahapan sebagai berikut;

1. Menyusun matrik indikator sebagai bahan pertanyaan untuk partisipan

2. Mengumpulkan informasi melalui wawancara (FGD dan Person Intervew) dan pengamatan lapang

3. Membuat tabulasi dan meletakkan informasi pada kriteria yang sama

4. Menginterpretasikan data

\section{HASIL DAN PEMBAHASAN}

\section{A. GAMBARAN UMUM DESA GONDOWANGI}

Secara administratif, Desa Gondowangi terletak di wilayah Kecamatan Wagir Kabupaten Malang dengan posisi dibatasi oleh wilayah desa-desa tetangga. Di sebelah Utara berbatasan dengan Desa Sidorahayu. Di sebelah Barat berbatasan dengan Desa Pandanrejo dan Sumbersuko. Di sisi Selatan berbatasan dengan Desa Mendalanwangi, sedangkan di sisi timur berbatasan dengan desa Parangargo Kecamatan Wagir. Desa Gondowangi merupakan desa yang terletak dekat dengan daerah perkotaan, atau sangat dekat pusat pemerintahan kota Malang. Dengan kata lain, Desa Gondowangi merupakan Desa Sub Urban. 


\section{B. ANALISIS DATA}

Analisis data dilakukan dengan interpretasi atas proses tahapan hasil pengumpulan data, tabulasi data yang telah dilakukan. Penyajian interpretasi dilakukan

a) Memiliki solidaritas sosial, yang terdiri dari indikator:

1) Kebiasaan gotong royong di desa; Desa gondowangi merupakan desa yang cukup memperhatikan nilai kearifan lokal yang ada. Budaya gotong royong masih cukup kental dijalankan dan dilestarikan meskipun desa tersebut merupakan daerah sub urban. Kebiasaan gotong royong ini diwujudkan dalam berbagai bentuk, misalnya kerja bakti lingkungan, acara warga, kegiatan bersama dan sejenisnya. Artinya tidak ada permasalahan terhadap budaya gotongroyong dan ini merupakan potensi yang perlu dibudayakan dan dilestarikan.

Pada indikator ini, sudah tidak ada permasalahan, hanya potensi ini perlu terus dijaga agar modal sosial tidak bergeser kearah sebaliknya.

2) Keberadaan ruang publik terbuka bagi warga yang tidak berbayar;

Secara khusus desa gondowangi telah menyediakan beberapa ruang publik yang tidak berbayar. Bentuk konkritnya seperti lapangan sepakbola. Hanya persoalannya pengelolaan yang perlu dioptimalkan seperti siapa yang mengelola dan bagaimana perawatannya.

3) Ketersediaanfasilitasataulapanganola hraga;

Terdapat fasilitas lapangan olah raga, berupa lapangan sepak bola. Potensi atas ketersediaan lapangan bola, belum difungsikan secara optimal, karena kondisi yang perlu perawatan dan pengelolaan yang lebih baik.

4) Terdapat kelompok kegiatan olahraga.

Kelompok kegiatan olah raga, sementara ini dilakukan oleh kelompok pemuda desa yang tergabung dalam karang taruna desa. Keberadaan karangtaruna mempunyai potensi yang besar mengingat mampu menghimpun dengan berbasis kepada indikator variabel IDM.

B.1 Indeks Ketahanan Sosial

(IKS);

1. Modal sosial; modal sosial kebersamaan dikalangan pemuda desa.

b) Memiliki toleransi, yang terdiridari indikator:

1) WargaDesaterdiri daribeberapasuku atau etnis;

Sebagaimana dalam profil desa, keberadaan warga desa hanya berasal dari satu etnis yaitu Jawa. Perjalanan sejarah desa menunjukkan bahwa tidak mengalami perubahan terhadap keberadaan dan keberagaman etnis di desa.

2) Warga Desa berkomunikasi sehari-hari menggunakan bahasa yang berbeda;

Bahasa yang digunakan dalam komunikasi keseharian, dominan menggunkan bahasa jawa. Dalam hal komunikasi formal digunakan bahasa Indonesia.

3) Terdapat keragaman agama di Desa.

Keberagaman agama di desa Gondowangi, terdiri dari 3 Agama yang dianut warga. Mayoritas adalah Islam, diikuti oleh Hindu dan Kristen. Keberagaman agama ini, cukup toleran antar pemeluk. Kuatnya modal sosial dimasyarakat mampu memperkuat ikatan sosial antar warga. Contoh dalam perayaan agama, setiap pemeluk agama dapat melaksanakan ibadat dengan tenang dan nyaman, bahkan dalam hal membutuhkan bantuan tenaga untuk penyiapan perayaan, maupun pelaksanaan selalu terjadi proses saling membantu.

c) Rasa aman penduduk, yang terdiri dari indikator:

1) Warga Desa membangun pemeliharaan pos kamling lingkungan;

Keberadaan pos kamling sudah merata ditiap dusun dan lingkungan RW serta beberapa RT. Pemeliharaan menjadi tanggungjawab wilayah terkecil dimana pos tersebut berada. Hal tersebut telah berjalan secara 
rutin.

2) Partisipasi warga mengadakan siskamling;

Partisipasi warga dalam pelaksanaan siskamling dilaksanakan secara rutin dengan pembagian jadwal oleh kepala komunitas warga dimana pos kamling berada. Menurut informasi dari para kepala dusun, pelaksanaan siskamling dapat berjalan rutin, meski juga terdapat beberapa kendala dalam pelaksanaan walaupun dalam prosentase kecil.

3) Tingkat kriminalitas yang terjadi di Desa;

Kriminalitas di desa gondowangi sudah jauh menurun dari tahun tahun sebelumnya, hal ini sesuai informasi yang disampaikan kepala desa. Problem kriminalitas juga tidak lepas dari keberadaan desa yang merupakan desa sub urban. Menurut epala desa, desa sub urban, tingkat pergaulannya juga terpengaruh oleh budaya kota, terutama kalangan pemuda yang masih menanggur. Pun demikian desa mempunyai potensi eksistensi gerakan organisasi pemuda karang taruna, yang menjadi media aktifitas pemuda desa.

4) Tingkat konflik yang terjadi di Desa; Berdasar observasi data desa dan dikuatkan oleh informasi partisipan, bahwa belum pernah terjadi konflik yang bersifat konflik sosial didesa. Budaya sosial yang kuat merupakan potensi yang mampu mencegah terjadinya konflik tersebut.

5) Upaya penyelesaian konflik yang terjadidiDesa.

Budaya guyub dan gotong royong merupakan potensi yang dimiliki desa. Sehingga upaya penanganan konflik lebih kearah antisipasi yang berjalan secara alamiah.

d) Kesejahteraan sosial, yang terdiri dariindikator:

1) Terdapat akses ke Sekolah Luar Biasa;

Secara geografis letak desa yang berjarak cukup dekat dekat dengan pusat kota, tentu akses ke pusat pelayanan menjadi lebih mudah termasuk SLB. Sehingga akses lebih mudah dijangkau. Kondisi masyarakat desa penyandang difabilitas sebagain kecil saja akan tetapi yang memanfaatkan SLB belum kesemuanya, hal ini karena ada rasa malu dari keluarga.

2) Terdapat penyandang kesejahteraan sosial (anak jalanan, pekerja seks komersial dan pengemis);

Budaya sosial dan budaya kerja didesa, cukup kuat mengikis adanya disparitas kesejahteraan sosial. Berdasarkan informasi bahwa didesa gondowangi tidak terdapat anak jalanan, PSK maupun pengemis. Adanya pengemis pun juga berasal dari luar desa.

3) Terdapat pendudukyang bunuh diri. Angka bunuh diri sangat kecil sekali dibandingkan dengan jumlah penduduk yang ada. Menurut informasi bahwa pernah terjadi 2 (dua) kali percobaan bunuh diri. Satu kasusnya sampai dengan meninggal karena faktor keputusasaan sakit menahun, satunya tidak sampai meninggal, karena faktor keharmonisan rumah tangga. Informasi yang didapatkan, yang gagal bunuh diri sudah mampu berbenah secara mental dan ekonomi sehingga sudah bisa hidup secara normal. Dengan permasalahan tersebut, desa melalui pemerintah desa cukup inten menggerakkan potensi desa, seperti kader kesehatan, peningkatan spiritual agar permaslaahan tersebut tidak terjadi.

2. Kesehatan;

a) PelayananKesehatan,yangterdiridarii ndikator:

1) Waktu tempuh ke prasarana kesehatan kurang dari 30 menit;

Secara geografis, letak desa godowangi yang tidak jauh dari pusat kota dan pusat pelayanan, memberikan akses yang relatif mudah dan cepat ke pusat pelayanan kesehatan. Puskesmas hanya berjarak $1 \mathrm{~km}$ waktu tempuh hanya 10 menit, Poskesdes/Polindes berada didesa, dan terdapat UGD fasilitas umum di 
tetangga desa bersebelahan.

2) Tersedia tenaga kesehatan bidan; Pemerintah melalui dinas kesehatan, telah menugaskan bidan untuk bertugas di Polindes Desa Gondowangi. Akan tetapi Bidan belum bisa tinggal/stay di polindes. Hal ini terjadi menngingat fasilitas tinggal/rumah dinas yang belum ada. Kondisi ini berdampak pada fungsi pelayanan bidan dipolindes hanya bersifat pelayanan/pengobatan dasar. Keberadaan Bidan saat ini tinggal dirumah pribadi yang berada di salah satu dusun di desa gondowangi serta membuka praktek pelayanan kesehatan di rumah (khususnya pelayanan bagi ibu melahirkan)

Berdasarkan indikator tersebut, maka permasalahannya adalah pelayanan belum optimal karena fasilitas yang belum memadai. Sedangkan potensi yang tersedia adalah keberadaan bidan yang telah dimobilisasi oleh pemerintah.

3) Tersedia tenaga kesehatan dokter; Tenaga kesehatan dokter berada pada pusat pelayanan kesehatan masyarakat yang berpusat di ibukota kecamatan. Pada indikator ini, sudah tidak terjadi permasalahan. Potensi keberadaan dokter ini dapat terus dioptimalkan dalam memberikan sandard pelayanan minimal dibidang kesehatan.

4) Tersedia tenaga kesehatan lain.

Keberadaan Tenaga kesehatan bertugas membentu bidan desa dalam pelayanan di polindes, saat ini berjumlah satu orang. tenaga kesehatan juga tidak tinggal/stay di polindes tetapi setiap hari berkantor di polindes.

Tenaga kesehatan lain adalah kader desa, fungsi kader desa ini adalah membantu pelayanan kesehatan khususnya di posyandu. Secara keahlian memang kompetensi belum sesuai dengan harapan (belum tersertifikasi dari bidang kesehatan). Hal ini menyebabkan banyak pihak meragukan (Desa dan masyarakat) Pelatihan kader yang selama ini telah dilaksanakan, belum mengcover secara keseluruhan jumlah kader desa yang ada yang ada, hanya sebagian yang telah mendapatkan pelatihan.

Pada indikator ini, masih terdapat permalasalahan tentang optimalisasi fungsi dan kompetensi, sedangkan potensinya adalah eksistensi kader/tenaga kesehatan serta keberadaan pemerintah desa yang siap memberi dukungan operasionalnya.

b) Keberdayaan Masyarakat untuk kesehatan, yang terdiri dari indikator:

1) Akses keposkesdes ,polindes dan posyandu;

Terdapat Poskesdes 1 unit dan posyandu pada tiap dusun. Posyandu terdiri dari posyandu reguler dan lansia. Permasalahan yang ada adalah peralatan yang belum lengkap beserta obat-obatan yang tersedia hanya untuk pelayanan kesehetan tingkat dasar. Sarana prasarana polindes belum memadai (fasilitas ruang rawat, bersalin belum ada), gedung kurang terawat, beberapa ornamen bangunan rusak, sehingga menimbulkan kerawanan keamanan.

Keberadaan Polindes, secara geografis berada pada dusun wiloso, dan akses nya pada daerah pinggir, sehingga dalam pemanfaatan polindes, masyarakat juga mempertimbangkan faktor kedekatan dengan pusat kesehatan lainnya, bagi lokasi yang jauh dengan polindes.

Pada indikator ini, permasalahan terletak pada kuaitas sarana prasarana yang berakibat pada fungsi pelayanan yang tidak optimal. Potensi yang dimiliki adalah keberadaan posyandu serta daya dukung pemerintah desa yang baik.

2) Tingkat aktivitas posyandu.

Aktifitas posyandu cukup baik dan frekuensinya rutin sesuai dan terjadwal. Fungsi pelayanannya adalah pelayanan kesehatan dasar, seperti timbang bayi, imunisasi, makanan tambahan dan pelayanan ringan lainnya. Permasalahan yang 
ada belum semua kader mendapatkan pelatihan yang memadai. Pelatihan pada kader yang ada belum tercover secara keseluruhan. Program penyadaran pentingnya ASI yang pernah dijalankan menurut bidan desa, dikatakan kurang berhasil.

Pada indikator ini, permasalahan lebih pada kompetensi kader, bagaimana perlu peningkatan kapasitas bagi seluruh kader kesehatan. Teknik penyadaran kepada masyarakat tentang nutrisi juga belum optimal. Potensi terhadap ini adalah keberadaan kader dan daya dukung pemerintah desa.

3) Jaminan kesehatan, yang terdiri dari indikator tingkat kepesertaan BPJS.

Belum semua warga mengikuti mengikuti program BPJS

Sebagian warga khususnya yang bekerja dipabrik, telah ditanggung oleh perusahaan. Untuk BPJS bersubsidi secara umum sudah terfasilitasi oleh pemerintah desa.

Pada indikator ini, permasalahan hanya pada intensifnya sosialisasi bagimana mendorong kepesertaan BPJS. Pun demikian ketersediaan kader kesehatan, pemerintah desa merupakan potensi yang dapat mengoptimakan sosialisasi.

3. Pendidikan;

a) Akses kePendidikan

DasardanMenengah,yang terdiri dari indikator:

1) Akses ke pendidikan dasar $\mathrm{SD} / \mathrm{MI}$ kurang dari 3 kilometer;

Akses ke pendidikan dasar SD/MI hanya berjarak $1,5 \mathrm{~km}$. Keberadaan desa gondowangi yang dekat dengan daerah urban, menjadikan akses ke pendidikan dasar selain yang berpusat di desa, juga dekat dengan akses pendidikan dasar SD/MI di kecamatan atau yang dekat dengan perkotaan.

2) Akses ke SMP/MTS kurang dari 6 kilometer;

Demikian juga akses ke pendidikan dasar SMP/MTS hanya berjarak 1,5 $\mathrm{km}$. Keberadaan desa gondowangi yang dekat dengan daerah urban, menjadikan akses ke pendidikan dasar selain yang berpusat di desa, juga dekat dengan akses pendidikan dasar SMP/MTS di kecamatan atau yang dekat dengan perkotaan.

3) Akses ke SMU/SMK kurang dari 6 kilometer

Sedangkan akses ke SMU/SMK berjarak kurang lebih $3 \mathrm{KM}$, dan berpusat di kecamatan.

Dalam hal akses ke pendidikan dasar SD/MI dan SMP/MTS serta SMU/SMK sudah tidak ada permasalahan. Kesadaran akan pentingnya pendidikan sudah cukup bagus.

b) AkseskePendidikanNonFormal,yang terdiridari indikator:

1) Kegiatan pemberantasan buta aksara; Tingkat buta aksara masih terdapat sebagian kecil dengan prosentase cukup rendah. Buta aksara hanya pada usia lanjut. Kemudian untuk remaja putus sekolah (kurang lebih 50 orang). Putus sekolah akibat efek lingkungan dimana desa gondowangi merupakan daerah sub urban. Program Paket yang ada adalah paket C belum terfasiitasi maksimal oleh desa. Kendala dalam pengelolaan paket $\mathrm{C}$ adalah minat belajar yang rendah bagi yang mengalami buta huruf/putus sekolah.

Potensi yang bisa diharapkan harus ada optimalisasi dari program paket $\mathrm{C}$ beserta dukungan pemerintah desa yang baik..

2) Kegiatan Pendidikan Anak Usia Dini;

Posyandu merupakan rangkaian kegiatan penanganan anak usia dini, dimana usia 0-1 tahun adalah usia bayi, 2-3 tahun adalah usia dini serta 4-5 adalah taman kanak-kanak. Sistem pelayanan terpadu ini telah tergarap oleh desa dengan adanya Posyandu, PAUD serta TK. Di desa Gondowangi Terdapat 2 unit pendidikan TK dan 4 unit PAUD. Permasalahan di tingkat pendidikan PAUD khususnya adalah, fasilitas bermain yang belum lengkap terutama safety motorik. Drai 
kualifikasi pengajar menurut pendmaping lokal PAUD, masih banyak guru PAUD yang belum linier pendidikannya, sehingga perlu mendapatkan penguatan kapasitas. Karena penguatan kapasitas yang ada belum mengcover keseluruhan kader/guru PAUD.

Potensi keberadaan PAUD dan TK ini yang dapat dioptimalkan pemanfatannya untuk mengurangi kesenjangan masalah yang ada.

3) Kegiatan Pusat Kegiatan Belajar Masyarakat/ Paket ABC;

Keberadaan PKBM/Paket C sudah diinisasiasi oleh desa dan sudah berjalan. Pun demikian masih ada permasalahan terutama menumbuhkan minat belajar khususnya bagi para orang tua. Adanya potensi sumberdaya eksisting beserta relawan desa merupakan bagian yang diharapkan dapat terus mengoptimalkan keberadaan keberlangsungan PKBM.

4) Akses ke pusat keterampilan/kursus. Posisi strategis desa sebagai desa sub urban adalah dekat dekat pusat pusat pelayanan masyarakat. Akses ke pusat ketrampilan lebih mudah dijangkau karena berada dipusat kota yang dekat dengan desa. Dalam hal ini telah dimanfaatkan walaupun dalam prosentase kecil.

c) Akses ke Pengetahuan, yang terdiri dari indicator taman bacaanmasyarakat atau perpustakaan Desa.

Pada indikator tersebut desa telah mempunyai taman baca atau perpustakaan desa. Tetapi terdapat permasalahan pemanfaatan oleh masyarakat dimana minat baca lebih banyak anak anak,sedangkan dari kalangan dewasa masih rendah. Selain itu masih perlu pengkayaan bahan literatur atau Bahan bacaan masih perlu diupdate.

Potensi dari pengelolaan perpustakaan desa ini, pengelolaan sudah cukup baik, hanya perlu mencari terobosan terobosan baru untu mendorong pemanfaatannya.
4. Permukiman.

a) Akses keair bersih dan air minum layak, yang terdiri dari indikator:

1) MayoritaspendudukDesamemilikisu mber air minum yang layak;

Air minum telah terpenuhi secara cukup, justru terdapat sumber yang melimpah yang tidak termanfaatkan dengan baik, sampai bak penampungan kalau malam meluber dan tidak termanfaatkan. Hal ini berpotensi merusak pipa air.

Menurut informasi dari petugas kesehatan, secara volume sudah terpenuhi, tetapi jika musim penghujan terkadang air menjadi keruh dan kurang layak minum, tetapi jarang terjadi.

Pengelolaan air minum ini sangat potensial dikembangkan, dan didesa saat ini sudah Bumdesa yang menangani yaitu PAM Desa.

2) Akses pendudukDesa memiliki air untuk mandi dan mencuci.

Potensi sumberdaya alam berupa sumber air, telah mampu dimanfaatkan dengan baik oleh masyarakat, sehingga untuk mandi dan mencuci sudah dapat memanfaatkan air yang ada, melalui PAM Desa.

b) Akses ke Sanitasi, yang terdiri dari indikator:

1) Mayoritas penduduk Desa memiliki jamban;

Berdasarkan informasi dari pemerintah desa, bahwa semua masyarakat telah memiliki jamban keluarga. Akan tetapi menurut pemerintah desa, masih ada sebgaian kecil warga yang $B A B$ di sungai, walaupun sudah memiliki jamban. Diperlukan mengoptimalkan potensi kepemilikan jamban bagaimana jamban dapat dmanfaatkan menjadi jamban keluarga.

2) Terdapat tempat pembuangan sampah.

Pemerintah desa telah menginisiasi penyediaan lahan khusus untuk tempat pembuangan sampah. Hanya saja alat transportasi sampah masih dirasakan kurang, sehingga belum 
menjangkau secara keseluruhan loaksi yang ada di tiap dusun. Permasalahan lainnya adalah, masih ada kebiasaan beberapa penduduk yang membuang sampah disungai, hal ini karena untuk lokasi yang tidak terjangkau kendaraan sampah (karena keterbatasan jumlah), membuat penduduk cenderung mengambil jalan pintas membuang sampah disungai.

Potensi tempat pembuangan sampah saat ini, telah dikelola dengan cukup baik, sudah ada pemilahan sampah organik dan anorganik (plastik). Pasca pemilahan sampah plastik dijual, sedangkan sampah organik dibuang dipinggr sungai untuk di bakar. Pada tataran inilah diperlukan tehnologi yang mampu mengolah sampah secara keseluruhan sehingga tidak menimbulkan masalah baru.

c) Akses ke Listrik, yang terdiri dari indikator jumlah keluarga yang telah memiliki aliran listrik.

Pada indikator ini, semua rumah penduduk telah terjangkau oleh jaringan listrik, dan setiap rumah sudah dapat mengakses listrik.

d) Akses ke Informasi dan Komunikasi, yang terdiri dari indikator:

1) Penduduk Desa memiliki telepon selular dan sinyal yang kuat;

Kepemilikan telepon, sudah hampir keseluruhan penduduk memilikinya. Sinyal cukup kuat mengingat daerah tersebut dekat dengan perkotaan. Sehingga untuk indikator tersebut sudah tidak ada permasalahan.

2) Terdapat siaran televisi lokal, nasional dan asing;

Siaran televisi lokal dan nasional sudah bisa diakses oleh semua penduduk,sedangkan televisi asing hanya sebagian penduduk yang mempunyai parabola atau TV berlangganan. Kepemilikan televisi, sudah hampir keseluruhan penduduk memilikinya. Sehingga untuk indikator tersebut sudah tidak ada permasalahan.

3) Terdapat akses internet.
Akses internet sudah cukup menyebar seiring dengan perkembangan smartphone yang dimiliki oleh hampir tiap keluarga. Desa juga mengembangkan web desa yang bisa diakses oleh penduduk maupun oleh pihak lannya. Melalui internet desa juga mengembangkan beberapa aplikasi diantaranya aplikasi keuangan desa. Dalam pengoperasiannya masih terdapat beberapa kendala, diantaranya masih masih belum sesuai denan harapan atas output laporan yang dihasilkan.

Potensi adanya akses internet inilah, yang dapat dikembangkan untuk meminimalkan beberapa kendala persoalan didesa.

\section{B.2 Indeks Ketahanan}

Ekonomi (IKE);

1. Keragaman produksi masyarakat desa, yang terdiri dari indikator terdapat lebih darisatu jenis kegiatan ekonomi penduduk.

Mata pencaharian penduduk;Tani, Buruh, Industri rumah tangga, dagang. Sehingga terdapat keberagaman produksi masyarakat terutama pertanian. Potensi pertanian diantaranya kayu, tebu, polowijo, padi.

Pengembangan tanaman padi, yang masih menjadi kendala diantaranya petani masih kesulitan mengembangkan pembibitan unggul, dimana harus selalu membeli diluar dengan harga relatif mahal.Jenis lahan sebelah utara irigasi baik, sedangkan sebelah selatan tadah hujan.

Pemerintah desa mulai mengembangkan sistem pengelolaan hasil pertanian terutama padi melalui Bumdesa. Skema yang dijalankan Bumdesa adalah dengan membeli padi dari petani kemudian diolah menjadi beras dan dikemas, kemudian dijual. Hal ini ternyata mampu meningkatkan harga padi dari petani dan menekan harga jual olahan, karena memangkas jalur distribusi.

2. Tersedia pusat pelayanan 
perdagangan, yang terdiri dari indikator:

a) Akses penduduk ke pusat perdagangan (pertokoan, pasar permanen dan semi permanen);

Sebagai daerah sub urban, maka desa gondowangi cukup dekat dengan pusat pusat perdagangan, diantaranya pasar permanen di desa sebelah. Sehingga akses penduduk ke pusat perdagangan sangat mudah, selain juga akses jalan yang mudah.

b) Terdapat sektor perdagangandipermukiman(warung danminimarket);

ra ekonomis, saat ini belum cukup memenuhi dalam pengembangan hotel maupun restoran.

3. Akses distribusi/logistik, yang terdiri dari indikator terdapat kantor pos dan jasa logistik.

Indikator ini hanya terpenuhi akses yang dekat kantor pos yang berpusat dikecamatan. Belum ada kendala terkait akses ke kantor pos, karena menang berada dipusat pemerintahan kecamatan yang daat diakses oleh seluruh desa se kecamatan wagir dengan mudah.

4. Akseskelembagakeuangandanper kreditan, yang terdiri dari indikator:

a) Tersedianya lembaga perbankan umum (pemerintah dan swasta);

Lembaga perbankan umum saat ini berpusat di kecamatan dengan status cabang atau cabang pembantu. Lembaga tersebut adalah BRI dan Swasta.

b) Tersedianya Bank Perkreditan Rakyat (BPR);

Bank Perkreditan Rakyat (BPR) berada di kecamatan. BPR tersebut milik pemerintah daerah maupun swasta.

c) Akses penduduk ke kredit.

Akses penduduk ke kredit yang disediakan oleh jasa perbankan umum maupun BPR, masih belum semua bisa mengakses, mengingat persyaratan usaha
Sektor perdagangan dipermukiman penduduk cukup beragam, diantaranya terdapat warung makan, warung klontong (pracangan). Terkait indikator ini sudah terpenuhi, hanya sektor perdagangan ini masih dikelola secara tradisional.

c) Terdapat usaha kedai makanan, restoran, hotel dan penginapan.

Terkait indikator ini, maka di desa Gondowangi hanya terdapat kedai makanan dalam skala sederhana. Restoran dan hotel maupun penginapan tidak ada, karena seca

yang belum bankable. Akses kredit saat ini, penduduk lebih banyak mengakses kredit ke UPK PNPM MPd karena dianggap mudah tanpa jaminan.

LembagaEkonomi,yangterdiridar iindikator tersedianya

lembagaekonomi

rakyat(koperasi);

Ketersediaan lembaga ekonomi rakyat berupa lembaga hasil dari pengembangan program PNPM MPd yang erpusat dikecamatan serta Koperasi Wanita yang juga merupakan hasil program yang bisa berkembang. Khusus Koperasi wanita, pengelolaan berpusat di desa dan berkantor di Balai Desa. Permasalahan didalam koperasi adalah pengelolaan manajerial yang masih perlu dioptimalkan. Potensi berdasarkan hasil wawancara, bahwa koperasi sudah mengembangkan aplikasi pembukuan komputerisasi. Potensi pengembanga pasar juga cukup luas dengan cakupan se wilayah desa Gondowangi.

5. Keterbukaanwilayah,yangterdirid ariindikator:

a) Terdapat roda transportasi umum (transportasi angkutan umum, trayek reguler dan jam operasi angkutan umum);

Pada wilayah jalur utama desa, merupakan jalur trayek resmi reguler angkutan desa. Sehingga 
untuk indikator tersebut sudah tidak ada persoalan, terkecuali pada akses jalan masuk ke dusun dusun yang harus dilalui dengan kendaraan pribadi.

b) Jalan yang dapat dilalui oleh kendaraan bermotor roda empat atau lebih (sepanjang tahun kecuali musim hujan, kecuali saat tertentu);

Berdasarkan informasi dari pemerintah desa, jalan jalan di desa sudah $80 \%$ lebih beraspal, dan untuk jalan tanah sudah padat. Kondisi ini dapat dengan mudah dilalui oleh kendaraan roda empat. Pada indikator ini maka pembangunan khususnya infrastruktur jalan sudah tidak bermasalah, hanya perlu memperhatikan aspek pemelihraan saja.

c) Kualitas jalan Desa (jalan terluas di Desa dengan aspal, kerikil dan tanah).

Kualitas jalan yang terluas adalah aspel, terdiri aspel hotmix untk jalan utama dan aspel lapen untuk jalan dusun. Selebihnya adalah jalan kerikil dan tanah pada akses jalan kecil di wilayah dusun.

B.3 Indeks Ketahanan Lingkungan (IKL).

1. Kualitas lingkungan, yang terdiri dari indikator:

a) Ada atau tidak adanya pencemaran air, tanah dan udara;

Pencemaran secara masif tidak terjadi, tetapi potensi pencemaran berpeluang terjadi. Dari informasi pada indikator sebelumnya, setidaknya ada 2 hal yang berpotensi mencemari yaitu sikap perilaku sebagian warga yang masih BAB disungai, serta pembuangan sampah serta pembakaran sampah organik dipinggir sungai.

Potensi yang bisa diandalkan dalam hal ini adalah ketersediaan jamban keluarga di tiap KK serta pengelolaan sampah yang sudah berjalaan selama ini.

b) Terdapat sungai yang terkena limbah.

Pencemaran limbah di sungai tidak ada. Sebagaimana indikator sebelumnya, bahwa hanya ada potensi pencemaran saja akibat pembuangan sampah, BAB disungai.

2. Potensi rawan bencana dan tanggap bencana, yang terdiri dari indikator:

a) Kejadian bencana alam (banjir, tanah longsor, kebakaran hutan); Sepanjang sejarah desa, belum pernah terjadi bencana alam seperti banjir, longsor maupun kebakaran hutan. Hal ini karena secara geografis tidak memungkinkan terjadi bencana seperti contoh diatas.

b) Upaya atau tindakan terhadap potensi bencana alam (tanggap bencana, jalur evakuasi, peringatan dini dan ketersediaan peralatan penanganan bencana).

Mengingat belum pernah ada bencana sebagaimana indikator sebelumnya, maka desa belum melakukan upaya penanganan. Hanya potensi pemerintah desa yang mempunyai daya dukung yang baik, maka bisa melakukan antisipasi kemunginan kemungkinan terjadi bencana walaupun tidak hanya terbatas pada 3 jenis bencana tersebut diatas, misalnya dengan pelatihan tanggap bencana

\section{KESIMPULAN DAN REKOMENDASI}

A. KESIMPULAN

Berdasarkan pembahasan penelitian di atas maka dapat kami sampaikan beberapa kesimpulan sebaga berikut;

a. Semenjak diberlakukannya Undang-undang nomor 6 tahun 2014 tentang Desa, maka desa mempunyai kewenangan untuk mengatur rumah tangganya sendidi berdasarkan hak rekognisi 
dan subsidiaritas. Dengan kewenangan ini maka desa perlu menata sedemikian rupa bagaimana menstrategikan pembangunan agar dapat menangani jerat masalah sesuai dengan potensi dan kearifan lokal yang ada.

b. Pembangunan desa sebagai upaya mewujudkan visi, perlu dirancang dengan pendekatan penilaian atas permasalahan dan potensi yang ada di desa. Pemerintah melalui kementrian desa telah menetapkan indikator untuk memotret indek kemajuan desa, sebagaimana permendesa nomor 2 tahun 2016 tentang Indeks Desa Membangun (IDM) yang terdiri dari 54 indikator. Dengan indikator inilah maka desa dapat menjadikannya sebagai instrumen atau alat ukur capaian pembangunan desa, sehingga pada indikator mana yang dinilai belum maupun telah tercapai dapat diketahui.

c. Desa Gondowangi merupakan desa dengan kategori sub urban, sehingga sifat masyarakatnya menyatu, tidak terpisah secara geografis. Sebagai bagian dari wilayah yang dekat dengan perkotaan, desa gondowangi dekat dengan pusat pelayanan masyarakat termasuk yang dibangun oleh desa. Artinya sarana dan prasarana desa khususnya terkait dengan pelayanan dasar telah terpenuhi, kalaupun kurang sifatnya hanya melengkapi saja dan hanya perlu optimalisasi pemanfaatan.

d. Hasil penelitian dengan pendekatan Community Based Research dapat diketahui adanya beberapa permasalahan tiap indikator dan potensi untuk menekan atau menyelesaikan atas permasalahan yang ada. Problem utama setidaknya peneliti melihat terdapat permalasahan utama di bidang kesehatan (pelayanan kesehatan, SDM dan prasarana), pendidikan dasar (SDM dan prasarana) , permukiman (sampah), dan perekonomian desa khususnya dibidang pertanian. Sedangkan potensi yang menunjang adalah ketersediaan SDM, Pemerintah desa yang progresiv, kearifan lokal yang sudah jalan seperti pengelolaan sampah, kemudian adanya kelembagaan ekonomi desa berupa Bumdesa yang sudah berjalan.

\section{B. REKOMENDASI}

Rekomendasi atas penelitian ini adalah;

a. Beberapa persoalan yang telah dianalisis berdasarkan indek desa membangun, khususnya pada indikator indikator yang dinilai lemah capainnya, perlu mendapatkan perhatian serius, dan mendalami akar masalah, sehingga dapat segera teratasi dengan strategi perencanaan pembangunan yang tepat. Pola penyelesaian harus tetap berbasis pada nilai kearifan lokal dengan memanfaatkan sumberdaya lokal yang ada.

b. Isu-isu yang berhasil digali secara empiris diantaranya adanya potensi air, Bumdesa, Pemerintah desa yang progresiv, potensi pengelolaan sampah, kuatnya budaya gotongroyong, perlu dirumuskan dengan mengkatkan antar isu yang ada,sehingga memunculkan tematik kegiatan sebagai bagian dari strategi pembangunan desa, dapat memunculkan kegiatan yang inovatif berkelanjutan tanpa meninggalkan nilai kearifan lokal dan diharapkan mampu memecahkan persoalan pembangunan desa.

c. Perlu kajian lanjutan, untuk mengerucutkan ide gagasan desa dalam pembangunan desa ke depan. 


\section{DAFTAR PUSTAKA}

Chirico, F., 2008, Knowledge Accumulation in Family Firms: Evidence from Four Case Studies. International Small Business Journal, $26: 433$.

Juraidah; (2015), jurnal penelitian "peran pemerintah desa dalam meningkatkan partisipasi masyarakat dalam pembangunan di Desa Mendik Kecamatan Longkali Kabupaten Paser" eJournal Administrasi Negara, 3 (4) 2015: 1145 - 1157 ISSN 0000-0000, ejournal.an.fisipunmul.ac.id (C) Copyright 2015

Khairuddin. 2005. Sketsa Kebijakan Desentralisasi Di Indonesia Format Masa Depan OtonomiMenuju Kemandirian Daerah, Averroes Press, Malang.

Mahayana Wayan; (2013) Jurnal penelitian "peran kepala desa dalam meningkatkan pembangunan desa di desa Bumi Rapak Kecamatan Kaubun Kabupaten Kutai Timur".eJournal Ilmu Pemerintahan, 2013, 1 (2): 400 - 414 ISSN 0000-0000, ejournal.ip.fisip-unmul.org Copyright 2013

Miles, M.B. \& Huberman, A.M., 1992, Analisis Data Kualitatif. Jakarta: UI Press.

Moleong, Lexy .J.2006. Metode Penelitian Kualitatif Edisi Revisi.Bandung : PT. Remaja Rosdakarya

Nawawi, Hadi. 2005. Metodologi Penelitian Sosial. Yogyakarta: Gajahmada University Perss

Permendesa nomor 2 tahun 2016, tentang Indeks Desa Membangun

Rosalina Maya; (2013) Jurnal penelitian kinerja pemerintah desa dalam pembangunan infrastruktur di desa kuala lapang dan desa taras kecamatan malinau barat kabupaten malinau. eJournal Pemerintahan Integratif, 2013, 1 (1): 106-120 ISSN 0000-0000, ejournal.pin.or.id (C) Copyright 2013

Siagian, Sondang P. 2003. Manajemen Sumber Daya Manusia. Penerbit : Bumi Aksara. Jakarta.

Undang undang nomor 6 tahun 2014 tentang Desa

Wahyuni, S., 2012, Qualitative Research Method: Theory and Practice (Vol. 1). Jakarta: Penerbit Salemba Empat. 